\title{
KONSENTRASI PENGENCERAN SALINITAS TERHADAP KEMAMPUAN OSMOREGULASI IKAN CAPUNGAN BANGGAI (Pterapogan kauderni)
}

\section{Concentration Dilution Salinity Towards The Ability of Fish Taken from Capungan Osmoregulasii}

\author{
Diterima : 20 Oktober 2017; Disetujui 2 Desember 2017
}

\author{
Samsu Adi Rahman ${ }^{1}$, Admi Athirah ${ }^{* 2}$, dan Ruzkiah Asaf ${ }^{1}$ \\ ${ }^{1}$ Dosen pada Fakultas Perikanan, Universitas Muhammadiyah Luwuk \\ ${ }^{2}$ Peneliti pada Balai Riset Perikanan Budidaya Air Payau dan Penyuluhan Perikanan \\ *Korespondesi : m.athirah@gmail.com
}

\begin{abstract}
ABSTRAK
Salah satu aspek yang sangat penting untuk diteliti adalah proses osmoregulasi ikan capungan banggai terhadap media air tawar. Penelitian ini bertujuan untuk mengetahui kemampuan osmoregulasi ikan capungan banggai (P. kauderni) terhadap pengenceran berbeda terhadap media salinitas. Penelitian dilaksanakan pada bulan Mei hingga bulan Juli 2016, sebagai hewan uji yaitu ikan capungan banggai dengan ukuran panjang adalah berkisar 3.5-6 cm 3-5 gram yang diperoleh dari hasil tangkapan kawasan terumbu karang sekitar perairan Kabupaten Banggai Kepulauan. Rancangan percobaan yang digunakan adalah Rancangan Acak Lengkap (RAL) dengan tiga perlakuan. Parameter yang diamati aitu kemampuan osmoregulasi, kelangsungan hidup dan parameter kualitas air. Data dianalisis dengan analisis ragam (ANOVA) dengan rancangan percobaan sehingga jika terdapat pengaruh yang nyata dari masing-masing perlakuan, maka akan di lanjutkan dengan uji BNT. Hasil penelitian menunjukkan ketiga perlakuan penurunan salinitas ikan capungan mengalami kerusakan organ ginjal dan insang pada minggu kelima dan mampu melakukan osmoregulasi, yaitu bertahan hidup pada kondisi air 5 ppt.
\end{abstract}

Kata kunci : ikan capungan, osmoregulasi, pengenceran, salinitas

\begin{abstract}
One of the aspects that are very important to fish osmoregulasi process is examined capungan banggai freshwater against the media. This research aims to know the capabilities of the osmore gulasi fish capungan banggai (p. kauderni) against the dilution media differently to salinity. Research conducted in May to July 2016, as test animals namely fish taken from capungan with the size of the length of the range is 3.5-6 cm 3-5 g obtained from the catch area of coral reefs around the Banggai Regency waters The Islands. The experimental design used was Complete Random Design (RAL) with three treatment. The parameters observed aitu osmoregulasi ability, survival and parameters of water quality. Data were analyzed with the analysis range (ANOVA) and experimental design so that if there is a noticeable influence from each treatment, then it will continue on with test BNT. The results showed a third treatments decreased salinity capungan fish organ damage kidneys and gills on the fifth week, and was able to do osmoregulasi, that survive on water conditions 5 ppt.
\end{abstract}

Keywords : Banggai, dilution, salinity, osmoregulation.

Samsu Adi Rahman dkk, Konsentrasi pengenceran salinitas terhadap kemampuan osmoregulasi ikan capungan banggai (Pterapogan kauderni) 


\section{PENDAHULUAN}

Ikan capungan banggai (Pterapogon kauderni) adalah ikan yang hanya terdapat diperairan kepulauan Banggai Propinsi Sulawesi Tengah dan di perjual belikan di dunia sebagai ikan hias dalam akuarium. Ikan capungan banggai termasuk salah satu potensi ekonomi yang harus dikelola dengan baik,sehingga dapat memberikan manfaat yang berkelanjutan bagi masyarakat dimasa sekarang dan masa akan datang kususnya Banggai Kepulauan (Allen dan Steene, 1995).

Mengingat usaha ekspor ikan hias air laut mempunyai prospek yang sangat baik dalam peningkatan pembangunan perekonomian di Indonesia, maka harus dikembangkan secara serentak melalui pola maju (intensif). Pola maju merupakan tekonologi tinggi yang dibarengi dengan input yang tinggi. Disamping itu usaha pemeliharaan ikan hias laut belum berhasil dikembangkan, karena pemeliharaan yang masih dianggap rumit. Salah satu usaha untuk mengatasi permasalahan tersebut adalah dengan cara manipulasi media pemeliharaan yaitu melalui penurunan salinitas sehingga ikan hias atau ikan capungan banggai mampu menyesuaikan hidupnya pada kondisi lingkungan yang berbeda. Usaha kearah manipulasi lingkungan merupakan salah satu alternatif kegiatan untuk menjaga estetika ikan capungan banggai untuk tetap digemari.

Penyesuaian ikan terhadap pengaruh lingkungan merupakan suatu homeostasis, dalam hal ini ikan akan mempertahankan keadaan yang stabil melalui suatu proses aktif melawan perubahan yang dimaksud. Homeostasis merupakan kecenderungan organisme hidup untuk mengontrol dan mengatur fluktuasi lingkungan internalnya (Affandi $d k k, 2002$ ).

Salinitas atau kadar garam adalah jumlah kandungan bahan padat dalam satu kilogram air laut, dalam hal ini seluruh karbonat telah diubah menjadi oksida, brom dan yodium yang telah disetarakan dengan klor dan bahan organik yang telah dioksidasi. Secara langsung, salinitas media akan mempengaruhi tekanan osmotik cairan tubuh ikan. Melalui penelitian ini, maka untuk mengetahui kemampuan ikan dalam beradaptasi melalui proses osmoregulasi, terhadap perubahan lingkungan, yang dimanipulasi dengan beberapa perlakuan pengenceran salinitas. Kemampuan ikan menyesuaikan diri pada salinitas tertentu, dapat digolongkan menjadi ikan yang mempunyai toleransi salinitas yang kecil (stenohaline) dan ikan yang mempunyai toleransi yang luas (euryhaline). Diharapkan dari penelitian ini ikan capungan banggai mampu bertoleransi lebih luas (euryhaline).

Untuk mencapai tujuan budidaya atau meningkatkan nilai estetika dalam ornament maka berbagai aspek budidaya dan pemeliharaannya mutlak harus diteliti secara terarah. Salah satu aspek yang sangat penting untuk diteliti adalah proses osmoregulasi ikan capungan banggai terhadap media air tawar.

Penelitian ini bertujuan untuk mengetahui kemampuan osmoregulasi ikan capungan banggai ( $P$. kauderni) terhadap pengenceran berbeda terhadap media salinitas. Penelitian ini dapat berguna asebagai sumber informasi terhadap upaya pemeliharaan dan perkembangan ikan hias laut. Selain itu diharapkan ikan capungan banggai bisa mentolerir lingkungan yang lebih luas (euryhaline).

\section{METODE PENELITIAN \\ Lokasi dan Waktu Penelitian}

Penelitian dilaksanakan pada bulan Mei hingga bulan Juli 2016 di Instalasi Stasiun Karantina Ikan, Pengendalian Mutudan Keamananan Hasil Perikanan Kelas

II Luwuk, Kabupaten Banggai, Propinsi

Samsu Adi Rahman dkk, Konsentrasi pengenceran salinitas terhadap kemampuan osmoregulasi ikan capungan banggai (Pterapogan kauderni) 
Sulawesi Tengah. Alat yang digunakan dalam penelitian ini adalah akuarium ukuran 70x40x40 cm2, aerator, selang aerasi, batu aerasi, salinometer, $\mathrm{pH}$ meter, termometer, tabung infus, timbangan, pipet tetes dan gelas ukur. Sedangkan bahan yang digunakan dalm penelitian ini yaitu, air laut, air tawar dan pakan pelet sebagai pakan organisme uji. Sebagai hewan uji, digunakan ikan capungan banggai (P. kaudernii) dengan ukuran panjang adalah berkisar 3.5-6 cm 3-5 gram yang diperoleh dari hasil tangkapan kawasan terumbu karang sekitar perairan Kabupaten Banggai Kepulauan.

Rancangan percobaan yang digunakan adalah Rancangan Acak Lengkap (RAL) dengan tiga perlakuan yaitu perlakuan $\mathrm{A}: 150$ $\mathrm{ml}$ air tawar/liter, B : $100 \mathrm{ml}$ air tawar/liter, C : $50 \mathrm{ml}$ air tawar/liter, dan masing-masing 3 ulangan, sehingga total perlakuan adalah 9 . Penempatan setiap unit percobaan dilakukan secara acak.

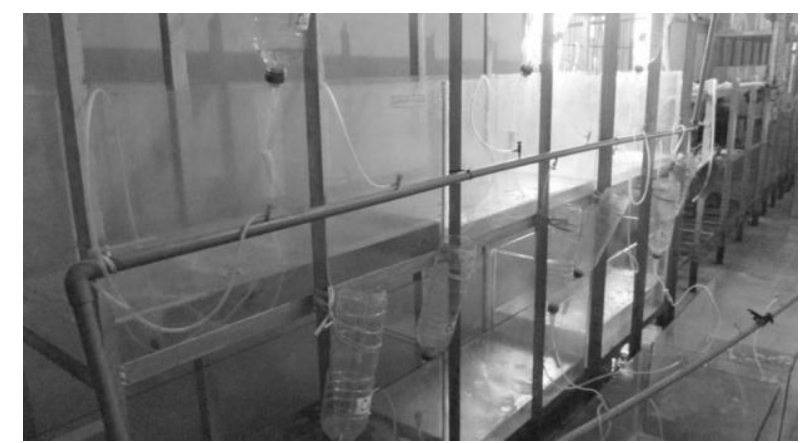

Gambar 1. Penempatan unit-unit percobaan

Organisme uji yang digunakan dalam

perlakuan diaklimatisasi di dalam akuarium yang telah berisi air dengan salinitas yang sama yaitu 35 ppt, serta aklimatisasi dilakukan selama 3 hari.

Setelah organisme uji diadaptasikan pada media bersalinitas yang sama kemudian dimasukan ke dalam akuarium dengan kepadatan sama yakni 10 ekor. Penyiponan sisa pakan dan feses ikan dilakukan seperlunya yang diharapkan mampu menjaga kualitas air di dalam sistem resirkulasi. Pakan diberikan secara satiasi (sedikit-sedikit) sebanyak 5\% dari bobot tubuh ikan, sedangkan frekuensi pemberian pakan dilakukan 2 kali sehari. Penambahan air dilakukan setiap hari sesuai dengan dosis air tawar masing-masing perlakuan, penambahan air tawar dengan cara membuka tabung infuse secara perlahan (Kasmi \& Rahman, 2015). Penelitian ini dilakukan selama 35 hari dan dilakukan pencatatan hasil yang diperoleh. Pengumpulan data diperoleh dari hasil pengamatan tingkah laku ikan dan tingkat kelangsungan hidup serta mengamati organ dalam pada ikan yaitu ginjal dan insang.

Kemampuan osmoregulasi diamati setiap hari dengan melihat keadaan organ yang berperan dalam osmoregulasi yaitu ginjal, insang dan kulit, serta mengamati tingkah laku ikan. Untuk melihat keadaan organ dalam ginjal dan insang dilakukan pengamatan secara visual dengan melihat perubahan bentuk dan warna pada ikan uji apabila terdapat mortalitas, untuk pengamatan tingkah laku ikan yang diamati ikan yang masih bertahan hidup.

Kelangsungan hidup merupakan presentase dari jumlah ikan yang hidup dan jumlah ikan yang di tebar selama pemeliharaan (Effendie, 1997), dapat dihitung dengan menggunakan rumus sebagai berikut:

$$
\mathrm{S}=\frac{\mathrm{N}_{\mathrm{t}}}{\mathrm{N}_{\mathrm{o}}} \times 100 \%
$$

$\mathrm{S}=$ Derajat kelangsungan hidup (\%)

$\mathrm{N}_{\mathrm{o}}=$ Jumlah ikan yang ditebar pada awal penelitian (ekor)

$\mathrm{N}_{\mathrm{t}}$ = Jumlah ikan yang ditebar pada akhir penelitian (ekor)

Data kualitas air meliputi pengukuran salinitas, suhu, dan $\mathrm{pH}$. Pengukuran parameter kualitas air ini dilakukan setiap pagi. Data yang diperoleh pada penelitian dianalisis dengan analisis ragam (ANOVA) dengan rancangan percobaan, sehingga jika terdapat pengaruh yang nyata dari masing-masing 
perlakuan, maka akan di lanjutkan dengan uji BNT (Beda Nyata Terkecil) (Gaspersz, 1991).

\section{HASIL DAN PEMBAHASAN}

\section{Kemampuan Osmoregulasi Ikan Capungan}

Hasil penelitian pengenceran salinitas terhadap kemampuan osmoregulasi ikan capungan banggai dengan tiga konsentrasi yang berbeda menunjukan perubahan pada organ yaitu ginjal, insang dan kulit seperti yang terlihat pada Tabel 1 .

Pada saat penebaran pertama ikan masih dalam keadaan normal setelah diberi pelakuan ginjal ikan terlihat pucat, insang pucat dan warna kulit pudar, hal ini karena kemampuan osmoregulasi mulai menurun, sehingga ikan sudah mulai bekerja keras, ginjal ikan mulai membesar karena tidak mampu menyerap air tawar, insang terlihat lebih pucat dan kulit lebih pudar kemudian berlendir. Pada kondisi ini ikan tidak mampu lagi menyesuaikan dengan tekanan osmotik yang ada di lingkungan.

Perubahan yang terjadi pada organ anatomi ikan disebabkan oleh tekanan osmotik atau osmoregulasi selama pemeliharaan, dimana pengenceran salinitas yang dilakukan pada penelitian menyebabkan proses fisiologis dalam tubuh ikan tidak berjalan dengan normal karena organ-organ anatomi ikan seperti ginjal, insang dan kulit sangat berperan dalam pengaturan osmoregulasi. Menurut Randall, et.al., (2001) dan Wilmer, et.al., (2010) bahwa osmoregulasi ikan dilakukan oleh organ-organ ginjal, insang, kulit, dan saluran pencernaan.

Tabel 1. Hasil pengamatan pada tubuh ikan yang telah mati selama penelitian

\begin{tabular}{llll} 
Perlakuan & Ginjal & Insang & Kulit \\
\hline $\mathrm{N}$ & Normal & Normal & Normal \\
$\mathrm{A}$ & Berlendir, membesar & Berlendir dan & Berlendir dan sangat pucat \\
$\mathrm{B}$ & dan sangat pucat & sangat pucat & \\
$\mathrm{C}$ & Mulai membesar & Lebih pucat & Pudar \\
\hline
\end{tabular}

Keterangan : $\mathrm{N}=$ Kontrol, $\mathrm{A}=150 \mathrm{ml}$ air tawar/liter, $\mathrm{B}=100 \mathrm{ml}$ air tawar/liter, $\mathrm{C}=50 \mathrm{ml}$ air tawar/liter

Tabel 2. Tingkah laku ikan capungan bagai yang masih hidup

\begin{tabular}{|c|c|c|c|c|c|c|}
\hline Perlakuan & $\begin{array}{c}\text { Salinitas } \\
\text { Awal 0 }\end{array}$ & $\begin{array}{l}\text { Salinitas } \\
\text { Minggu } 1\end{array}$ & $\begin{array}{c}\text { Salinitas } \\
\text { Minggu } 2\end{array}$ & $\begin{array}{l}\text { Salinitas } \\
\text { Minggu } 3\end{array}$ & $\begin{array}{c}\text { Salinitas } \\
\text { Minggu } 4\end{array}$ & $\begin{array}{c}\text { Salinitas } \\
\text { Minggu } 5\end{array}$ \\
\hline $\begin{array}{l}\text { A } 150 \mathrm{ml} \text { air } \\
\text { tawar }\end{array}$ & Aktif & Aktif & $\begin{array}{l}\text { Gerakan } \\
\text { lambat dan } \\
\text { warna } \\
\text { memudar }\end{array}$ & $\begin{array}{l}\text { Gerakan } \\
\text { naik turun }\end{array}$ & $\begin{array}{l}\text { Ikan sudah } \\
\text { mulai } \\
\text { hilang } \\
\text { keseimban } \\
\text { gan }\end{array}$ & Pasif \\
\hline $\begin{array}{l}\text { B } 100 \mathrm{ml} \text { air } \\
\text { tawar }\end{array}$ & Aktif & Aktif & $\begin{array}{l}\text { Gerakan } \\
\text { lambat dan } \\
\text { warna } \\
\text { memudar }\end{array}$ & $\begin{array}{l}\text { Gerakan } \\
\text { naik turun }\end{array}$ & $\begin{array}{l}\text { Ikan diam } \\
\text { dan } \\
\text { berkumpul }\end{array}$ & Pasif \\
\hline $\begin{array}{l}\text { C } 50 \mathrm{ml} \text { air } \\
\text { tawar }\end{array}$ & Aktif & Aktif & $\begin{array}{l}\text { Gerakan } \\
\text { lambat dan } \\
\text { warna } \\
\text { memudar }\end{array}$ & $\begin{array}{l}\text { Gerakan } \\
\text { naik turun }\end{array}$ & $\begin{array}{l}\text { Ikan diam } \\
\text { dan } \\
\text { berkumpul }\end{array}$ & Pasif \\
\hline
\end{tabular}

Samsu Adi Rahman dkk, Konsentrasi pengenceran salinitas terhadap kemampuan osmoregulasi ikan capungan banggai (Pterapogan kauderni) 
Berdasarkan hasil pada Tabel 2 berikut maka dapat dilihat bahwa tingkah laku ikan pada masing masing perlakuaan setiap minggu. Pada perlakuan A $(150 \mathrm{ml}$ air tawar/liter), B (100 ml air tawar/liter) dan C (50 $\mathrm{ml}$ air tawar/liter) merupakan penebaran awal, dimana kondisi salinitas pada saat itu masih optimal, yaitu 35 ppt sehingga gerakan ikan masih normal atau aktif.

Pada minggu pertama ikan masih tetap aktif pada masing-masing perlakuan karena pada kondisi tersebut ikan masih mentolerir salinitas pada masing-masing perlakuan. Pada minggu kedua setelah diberi perlakuan, ikan capungan sudah mulai menampakkan gejala gerakan lambat dan warna memudar. Sedangkan minggu ketiga gerakan ikan sudah mulai naik turun, berenang lambat, hal ini dikarenakan karena adanya proses osmoregulasi dimana ikan capungan mulai menyeimbangkan tekanan osmotik yang ada di dalam air dan di luar tubuhnya, selanjutnya pada minggu keempat tingkah laku ikan banyak diam dan ikan sudah mulai hilang keseimbangan, hal tersebut diduga pembelanjaan energi untuk osmoregulasi tinggi shingga energi kurang dan menyebabkan kematian. Kemudian pada minggu kelima pada semua perlakuan ikan mulai mengalami kematian, dimana salinitas perlakuan A (13 ppt), dan perlakuan B (7 ppt) dan C (5 ppt).

Menurut Affandi (2002) bahwa organisme mempunyai kemampuan yang berbeda-beda untuk menghadapi masalah osmoregulasi sebagai respon atau tanggapan terhadap perubahn osmotik lingkunganya eksternalnya. Perubahan kosentrasi ini cenderung mengganggu kondisi internal. Untuk menghadapi masalah ini cenderung hewan melakukan pengaturan tekanan osmotik dengan cara mengurangi gradient osmotik antara lain cairan tubuh dengan lingkungannya. Ikan yang tidak mampu menyesuaikan diri dengan perbedaan tekanan osmotik antara cairan tubuh dan lingkungan akan mengalami degradasi atau menyebabkan terjadinya mortalitas.

\section{Sintasan}

Berdasarkan hasil pengamatan yang diperoleh dari rata-rata sintasan (Gambar 2) sebagai berikut:

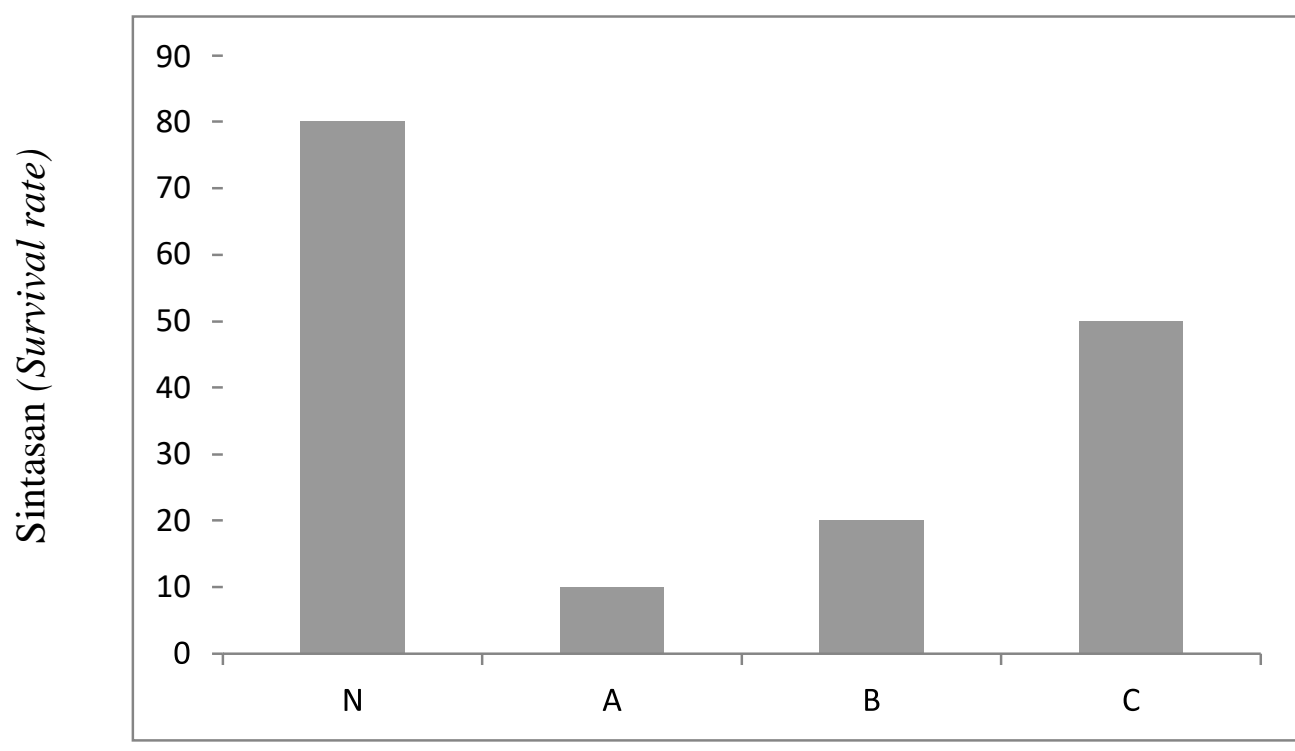

Perlakuan (Treatments)

Gambar 2. Grafik sintasan ikan capungan banggai

Samsu Adi Rahman dkk, Konsentrasi pengenceran salinitas terhadap kemampuan osmoregulasi ikan capungan banggai (Pterapogan kauderni) 
Grafik di atas menunjukan hasil ratarata sintasan dari setiap perlakuan selama penelitian, dimana dari jumlah tebar awal pada semua perlakuan masing-masing 10 ekor/wadah. Hasil Uji Analisis Ragam diperoleh bahwa ketiga perlakuan penurunan salinitas terhadap sintasan berbeda nyata. Sintasan yang sangat rendah menunjukan bahwa ikan capungan tidak dapat menyesuaikan diri dengan penurunan salinitas yang dilakukan. Pada minggu kedua sampai minggu kelima ikan sudah mengalami gejala klinis dan pada akhir penelitian, yaitu minggu kelima perlakuan A (10 ekor), B (20 ekor), C (50 ekor) dan $\mathrm{N}$ (80 ekor).

Hewan uji yang bertahan pada masingmasing perlakuan diduga karena masih mampu tergadap tekanan osmotik dari luar. Berdasarkan masing-masing perlakuan tekanan osmotik perlakuan A lebih tinggi dari perlakuan B, C dan kontrol. Tekanan osmotik ini mempengaruhi tingkat keberlangsungan hidup ikan capungan banggai, sehingga semakin kecil tekanan osmotik semakin besar tingkat kelangsungan hidup ikan dan sebaliknya semakin besar tekanan osmotik, maka kelangsungan hidup ikan menurun. Hal ini berkaitan dengan proses osmoregulasi yang terjadi pada ikan.

\section{Parameter kualitas air}

Hasil pengukuran kisaran kualitas air selama penelitian tersaji pada Tabel 3 berikut.

Tabel 3. Kisaran Kualitas Air Masing-Masing Perlakuan Selama Penelitian

\begin{tabular}{ccc}
\hline Perlakuan & \multicolumn{2}{c}{ Kualitas Air yang diamati } \\
\hline A 150 ml air tawar/liter & Suhu (temperature) $(0 \mathrm{C})$ & $\mathrm{pH}$ \\
B 100 ml air tawar/liter & 25 & $6-7$ \\
C 50 ml air tawar/liter & 25 & $7-7,5$ \\
\hline
\end{tabular}

Tabel 3 menunjukan bahwa kisaran kualitas air pada masing-masing perlakuan masih dalam kisaran yang layak untuk menunjang keberlangsungan hidup ikan capungan, dimana suhu air selama penelitian $25^{\circ} \mathrm{C}$ dan $\mathrm{pH}$ 7,5-8. Sedangkan menurut Tullock (1998) bahwa suhu yang baik untuk akuarium laut berkisar $24-27^{\circ} \mathrm{C}$. Menurut Siahaya (2010) pada saat musim timur (Juli) curah hujan relatif tinggi sehingga salinitas dan $\mathrm{pH}$ lautnya menjadi lebih rendah dibandingkan saat musim barat.

Selanjutnya Ahmad (2009) menyatakan bahwa air laut biasanya bersifat alkalis dengan pH lebih dari 7 karena banyak mengandung garam yang bersifat alkalis. Sedangkan menurut Brotowidjoyo et al. (1995) pada umumnya perairan laut maupun Samsu Adi Rahman dkk, Konse
banggai (Pterapogan kauderni) pesisir memiliki $\mathrm{pH}$ relatif lebih stabil dan berada dalam kisaran yang sempit, biasanya berkisar antara 7,6 - 8,3 yang berarti bersifat basa atau disebut alkali. Air yang banyak mengandung $\mathrm{CO}_{2}$ biasanya mempunyai $\mathrm{pH}$ lebih rendah dari 7 dan bersifat asam. Derajat keasamam $(\mathrm{pH})$ air sebesar 6,5-9,0 sangat memadai bagi budidaya ikan.

\section{KESIMPULAN}

Berdasarkan hasil penelitian mengenai kosentrasi pengenceran terhadap kemampuan osmoregulasi ikan capungan banggai (Pterapogon kauderni) dapat disimpulkan bahwa pada ketiga perlakuan penurunan salinitas ikan capungan mengalami kerusakan organ ginjal dan insang pada minggu kelima. Ikan capungan banggai mampu melakukan tas terhadap kemampuan osmoregulasi ikan capungan 
osmoregulasi, yaitu bertahan hidup pada kondisi air 5 ppt. Selain itu, perlu dilakukan penelitian lanjutan mengenai konsentrasi yang lebih kecil untuk melihat optimalisasi osmoregulasi ikan capungan banggai.

\section{Ucapan Terima Kasih}

Penulis menyampaikan terima kasih dan penghargaan yang sebesar-besarnya kepada seluruh teknisi laboratorium fakultas perikanan Universitas Muhammadiyah Luwuk selama kegiatan penelitian dilakukan dan pada seluruh pihak yang membantu sehingga penelitian ini dapat dipublikasikan.

\section{DAFTAR PUSTAKA}

Affandi, T.K, Manik, B., Rosadi, M., Utomo., M., Senge., Adachi, dan Oki. (2002). Soil Erosion Under Coffe Trees with Different Weed Management in Humid Tropical Hilly Area of Lampung. South Sumatera, Indonesia.

Ahmad, A (2009). Keasaman Laut (pH) Indonesia. Pustaka Setia: Bandung.

Allen, G and R.C. Steene. (1995). Notes on the Ecology and Behaviour of the Indonesia cardinal Fish (Apogonidae). Rev for Aquariol.

Brotowijoyo, M. D., Dj. Tribawono., E. Mulbyantoro., 1995. Pengantar Lingkungan

Perairan dan Budidaya Air. Liberty: Yogyakarta.

Effendie., M. I. (1997). Biologi Perikanan. Yayasan Pustaka Nusatama. Bogor.

Gaspersz. (1991). Metode Perancangan Percobaan. CV. Annico. Bandung. Hal. 33 - 35 .
Kasmi M, Rahman SA. (2015). The Dosage of Saline Water Dilution on The Osmoregulatory Capacity of Clownfish (Amphiprion ocellaris). IOSR Journal of Agriculture and Veterinary Science (IOSR-JAVS). Vol 8 (I):74-78.

Randall,D.,W. Burggren, \& K.French. (2001). Animal Physiology: Mechanisma and Adaptations. W.H. Freeman and Company. New York.

Tullock, J .H. (1998). Clownfishes and Sea Anemones. Barron's. Wireless Boulevard.

Wilmer, J.B., Germine, L., Chabris, C.F., Chatterjee, G., Williams, M., Loken, E.,et. al. (2010). Human Face Recognition Ability Is Specific And Highly Heritable. Proc.Nat.Acad.Sci.USA 107, 52385241.doi:10.1073/pnas.0913053107.

Samsu Adi Rahman dkk, Konsentrasi pengenceran salinitas terhadap kemampuan osmoregulasi ikan capungan banggai (Pterapogan kauderni) 